\title{
Natural conditions for the development of sustainable agriculture in the eastern part of the Łowicko-Błońska plain
}

\begin{abstract}
In present times, when human interference in nature can be quite substantial, solutions are needed to protect the natural environment. Sustainable farming is much more beneficial to the environment than traditional one. The Łowicz-Błonie Plain, and its eastern part in particular, has good soil and climatic conditions which can support the development of agriculture and the water conditions are only slightly worse here than in the neighbouring areas. The tessellated nature of the soils supports a wide variety of crops, which in turn allows farmers to plan crop rotation so as to enrich the region's biodiversity and protect nature.
\end{abstract}

Keywords

The Łowicko-Błońska Plain • sustainable agriculture

- integrated and organic $\cdot$ nature components

(C) University of Warsaw - Faculty of Geography and Regional Studies

\author{
Braun Barbara ${ }^{1}$ \\ Brzozowska Justyna² \\ ${ }^{1}$ Institute of Physical Geography, \\ Faculty of Geography and Regional Studies, \\ University of Warsaw \\ e-mail: bjbraun@uw.edu.pl \\ ${ }^{2}$ Institute of Physical Geography, \\ Faculty of Geography and Regional Studies, \\ University of Warsaw \\ e-mail: justynabrzozowska@gmail.com
}

Received: 7 March 2012

Accepted: 2 April 2012
Introduction, aims and methods

Agriculture is a sector of the economy that influences the natural environment both directly and indirectly. Traditional and industrial farming not only alters the soil and water conditions, but also affects the animal and plant life of agrosystems (Horrigan, Lawrence \& Walker 2002). Sustainable farming, and organic farming in particular, are activities that are much more beneficial to the natural environment (Stolze et al. 2000).

The fundamental principle of sustainable agriculture is to introduce the least possible amount of foreign matter so as to preserve the best possible environment quality for future generations (Horrigan, Lawrence \& Walker 2002). Sustainable agriculture aims to reconcile various aspects of the uncontaminated environment with socio-economic profitability (Horrigan, Lawrence \& Walker 2002; Rodriguez et al. 2008). In order to more effectively protect the environment and plants against pests and diseases, sustainable farming recommends appropriate crop rotation (Corselius, Wisniewski \& Ritchie 2001; Robak 2007) i.e. that there should be an interval of at least four years between the cultivation of crops of the same species in any particular field (Szwejda 2007). Practices such as crop rotation and the use of intercrops and aftercrops are measures that slow down the spreading of weeds, diseases and pests, help preserve favourable soil structure and maintain the desirable chemical and physical features of the soil and its biological activity. They also help prevent soil erosion in areas with pronounced relief (Corselius, Wisniewski \& Ritchie 2001; Smagacz 2007;
Szwejda 2007). Tree planting as well as the cultivation of semi-wild varieties of plants (Horrigan, Lawrence \& Walker 2002) also play an important role in the development of biodiversity and the conservation of agrosystems (Bałazy, Weyssenhoff \& Ziomek 2007).

Sustainable agriculture refers to two basic types of farming: organic and integrated. On organic farms, man-made chemicals (i.e. pesticides, growth regulators, artificial additives to fodder and mineral fertilisers) are not used and only the use of calcium fertilisers is permitted (Stolze et al. 2000). However, farming in this way requires substantial outlays in terms of time and labour and for this reason, organic farming is recommended mainly to small farms. These farms are usually self-sustaining, a feature which also makes it possible to contain the circulation of matter within the farm's system of soil, plants and animals (Ciećko et al. 2007; Horrigan, Lawrence \& Walker 2002; Stolze et al. 2000).

The main goal of integrated farming is the proper selection of plants that are suited to the specific environmental conditions of the farm in order to ensure satisfactory crop yields and thereby reduce mineral fertilisation and use of pesticides. Important components of both integrated and organic farming approaches are associated with the development of the agricultural landscape by ensuring desirable proportions for the layout of fields, meadows and pastures, and the enrichment of the landscape through the addition of field margin trees, ponds and nesting boxes for birds (Balkiewicz 2007; Faber 2007; Stolze et al. 2000). 
The aim of the analysis was to evaluate the natural potential of the eastern part of the Łowicko-Błońska Plain with a view of assessing the possibilities for the development of sustainable agriculture. An analysis of the natural conditions (mostly soils) was carried out for several dozen arable crops, followed by an evaluation of the conditions for their cultivation using the principles of integrated and organic farming. The soil conditions for the purposes of sustainable agriculture were evaluated on the basis of soil and agricultural maps at a scale of 1:100,000 as well as detailed geological maps at a scale of 1:50,000. Interviews were conducted with farmers who hold organic farming certificates and live in the area. The distribution of certain crops in the eastern part of the Plain was illustrated on the basis of a textbook titled Gleboznawstwo by Dobrzański \& Zawadzki (1981). Maps were prepared within the boundaries of nature units delineated on the basis of soil and farming complexes. Soil and farming complexes which are associated with specific arable crops. The following criteria were taken into account when delineating such complexes: the type and properties of soils, location of the soil in the relief, soil moisture and climatic conditions, and suitability (or lack of) of the soil for agriculture (Dobrzański \& Zawadzki 1981).

\section{Natural conditions of the eastern part}

of the Kowicko-Błońska Plain and crops proposed for cultivation

An analysis of the development prospects of sustainable agriculture focusing on the natural conditions was carried out for the eastern part of the Łowicko-Błońska Plain. The Łowicko-Błońska Plain is situated in the central Masovian Lowland in central Poland (Fig. 1). The area in question is delineated by the Skierniawka, Bzura, Utrata rivers and the southern border of the ŁowickoBłońska Plain (see Fig. 1).

The relief of the Łowicko-Błońska Plain is flat. The area in question is situated within the range of the Warthenian glaciation of the Pilica stadial (Kosmowska-Suffczyńska 2005). In the early and middle stages of the Pleistocene epoch, varved clay was deposited in the former lakes of the Warsaw Basin (Różycki 1972; Wicik 1992), which may have affected the soil properties in some

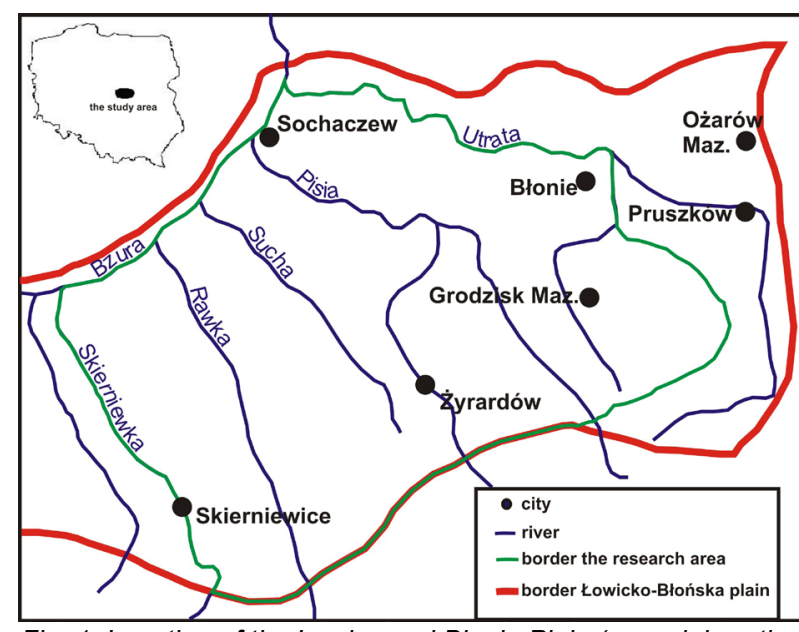

Fig. 1. Location of the Łowicz and Błonie Plain (own elaboration based on Kondracki, 1998) places. The flat character of this area offers good conditions for the development of agriculture and the lack of depressions means that the local climatic conditions are uniform.

The climatic conditions in the Łowicko-Błońska Plain are favourable for farming. The vegetation period in the ŁowickoBłońska Plain lasts approximately 215 days (Olszewski 2003) - the longest in central Poland. The Łowicko-Błońska Plain is also among the warmest regions of Poland, with average temperatures of $-2^{\circ} \mathrm{C}$ in winter and $+18^{\circ} \mathrm{C}$ in summer (Olszewski 2003). According to Woś (1999), the central part of the Mazovian region is characterised by a high number of warm and cloudy days when compared with the rest of Poland (63 days per year), with only 38 very cold or frosty days per year.

The area of the Łowicko-Błońska Plain shows periodic water shortages and the moisture deficiency means that it is necessary to cultivate plant varieties that are more resistant to periodic water shortages or to develop field irrigation networks. The average annual precipitation for the Mazovian region is $500-550 \mathrm{~mm}$ (Olszewski 2003), which is low when compared to 630mm (approx.) for Poland (Stopa-Boryczka \& Boryczka 2006). The period of snow cover is relatively short and lasts only about 3 to 4 months (Olszewski 2003), which may accelerate the plant vegetation period but could also negatively affect the water resources in the soil. The relatively similar climatic conditions across the Łowicko-Błońska Plain do not result in any major differences in plant crops.

The area of the whole Łowicko-Błońska Plain is situated in the catchment of the Bzura river, a tributary of the Vistula. Other tributaries of the Vistula in this area include the Utrata, Pisia, Sucha, Rawka and Skierniawka rivers. According to the data published by the Voivodeship Inspectorate for Environmental Protection (WIOŚ), in 2008 these rivers were graded as 4th and 5th quality classes (http://www.wios.lodz.pl, http://www.wios.warszawa.pl).

The first groundwater level is found at a depth of 2-5 $\mathrm{m}$ below ground level and rarely deeper (Pączka 1993). Subsurface waters are also frequently encountered in the Łowicko-Błońska Plain, usually at a depth of 1-3 m below ground level (Dobak D. 2003). Plants use these subsurface waters more frequently than they use groundwater. Subsurface waters are susceptible to weather changes and can disappear in dry periods, while their temperature is also correlated with the air temperature which means that in winter, these shallowly-situated subsurface waters can (and do) freeze. The hydrological system in the Łowicko-Błońska Plain is susceptible to changes in the climate conditions so access to water could well be a factor which will hamper the cultivation of some plants.

The region of the Łowicko-Błońska Plain is built from glacial and fluvioglacial deposits of the Warthenian glaciation (Dobak P. 2003). Surface deposits determine the soil nutrient content, its permeability and ability to retain water. The cohesion, viscosity and plasticity of the deposits affect the shape of the roots and tubers and can also determine the methods of cultivation.

The northern and western parts of the area studied are dominated by boulder clay deposits, with the occasional presence of sands and gravels deposited by terminal moraines. Its northeastern part is characterised by tessellated boulder clay and 
loams, while the southern part is built up of fluvioglacial sands and gravels as well as aeolian sands. Alluvial sands and gravels, occasionally loams and silts as well as humus sands and peaty silts, can be found along the river valleys.

Cambisols and luvisols evolved on clays and loams and these soils are regarded as very good for the growing of rye and good for the growing of other cereals and fodder plants.

Mollic gleysols can also be found in small depressions where the groundwater level is closer to the ground surface. These are the most fertile soils in the region, regarded as suitable or very suitable for the growing of wheat. Cambisols and mollic gleysols are used as arable land. Poor quality podzols and brunic arenosols devolved on sand and gravel deposits and these soils are regarded as good, poor or very poor for the growing of rye. Forests grow on the poorest-quality podzol soils and these are usually pine coniferous forests with birch and aspen. The remaining podzols are used as poor-quality arable land and grasslands. Fluvisols were formed on alluvial deposits while histisols formed on humus sands and peaty silt. These soils are most typically used as grassland, with alder carrs frequently encountered in wetter areas.

The northern area of the eastern part of the Łowicko-Błońska Plain is characterised by fertile soils with a considerable degree of tessellation of soils and surface deposits which supports a whole variety of plants grown here. Conversely, the southern area has fewer fertile soils and these are frequently used as grasslands. Many of these areas are suitable for afforestation.

On the basis of the natural conditions (mostly the geological substratum, soils and land use), three types of areas well-suited for organic, integrated and intensive farming have been identified in the eastern part of the Łowicko-Błońska Plain (Fig. 2).

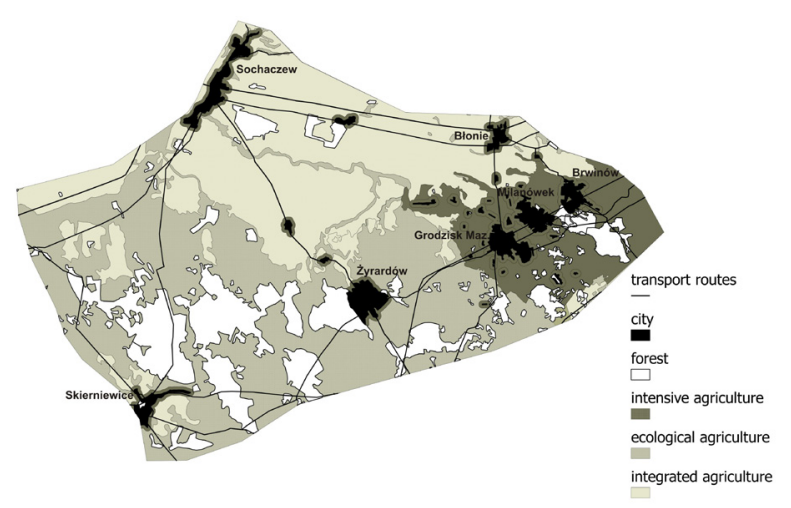

Fig. 2. Division of the eastern part of the Łowicz and Błonie Plain into areas with integrated, organic and intensive farming. Prepared by the authors on the basis of soil agricultural map $(1: 100000,1989)$

The south-eastern part of the region adjoins the Warsaw agglomeration (Fig. 1). The larger towns located in this area, namely Piastów, Pruszków, Brwinów, Milanówek, Grodzisk Mazowiecki, Żyrardów and Błonie are generally sited along the railway lines (Fig. 1). In this area, the development of sustainable agriculture is not recommended owing to the possibility of soil contamination by local industry. It has been assumed that the area within a ra- dius of $30 \mathrm{~km}$ from urbanised areas can be used by conventional agriculture (Fig. 2) and as a result, this area is not taken into account in our further analysis.

Conditions for the development of integrated agriculture are favourable in the northern part of the region, with good and very good soil, climatic and water conditions. The natural potential of the area makes possible the reduction of the use of artificial substances and replacement with natural fertilisers. With the use of natural plant-based products for protection, the volume of crops produced should be similar. On the other hand, the southern part of the region seems better suited for organic farming, owing to its poorerquality soils. Furthermore, the grasslands of the Łowicko-Błońska Plain offer good prospects for the development of organic farming and breeding. In some of the EU member states (e.g. Austria, Denmark, Belgium, Finland, France, Greece, Spain, the Netherlands, Ireland, Luxembourg, Germany, Portugal, Sweden, United Kingdom and Italy), considerable areas of land are used as meadows and pastures, particularly where the soils are of poorer quality (Organic farming in the European Union 2005). EU-funded agri-environment payment schemes make it possible for farmers to engage in organic farming without incurring financial losses. In Poland, typical agri-environment payments are approximately $600 \mathrm{PLN} / \mathrm{ha}$ (ca. $€ 137.50$ per hectare) and 260 PLN/ha (ca. €60 per hectare) for grasslands (Program rolnośrodowiskowy, Plan Rozwoju Obszarów Wiejskich 2007-2013). The use of natural fertilisers reduces the contamination of water and soils which is of great significance in this region due to the presence of protected areas in its southern part, such as the Bolimów Landscape Park, the "River Rawka Valley" and the "Bolimów Forest Clearing", which have been incorporated into the Natura 2000 network. Another argument in favour of the development of organic farming in the southern part of the Łowicko-Błońska Plain is the presence of over a dozen farms with certification for organic farming and breeding. Interviews conducted with farmers indicate that organic breeding can be a profitable activity provided that it is supported by agri-environmental payments.

The majority of the arable crops (rye, spring and winter wheat, spring and winter barley, oats, buckwheat, potatoes, swede, sugar and fodder beet, carrots, bird's foot, white, black and Sarepta mustard, maize, spring and winter rape, white and red clover, field peas, lupine, peas, alfalfa) analysed as part of this study give at least a satisfactory yield within the boundaries of the areas with integrated farming. In these areas (see Fig. 2) the most popular arable crops in Poland (rye, wheat, spring and winter barley (Fig. 5), oats and potatoes (Fig. 4), sugar and fodder beet (Fig. 6), rape (Fig. 3) and also maize in recent years), have good or very good natural conditions for cultivation and typically they can be grown under crop rotation schemes. The use of intercrops and aftercrops is recommended in order to fertilise the soil using natural methods and to protect it (e.g. against aeolian erosion), and aftercrops such as bird's foot, field peas, white (Fig. 7) and red clover as well as lupine can be effectively grown in this area.

The cultivation of most of the aforementioned plants is not profitable in the poor-quality soils in the areas designated for the development of organic farming. The only crops which should be grown there are barley, potatoes, oats, anchovy and occasionally 


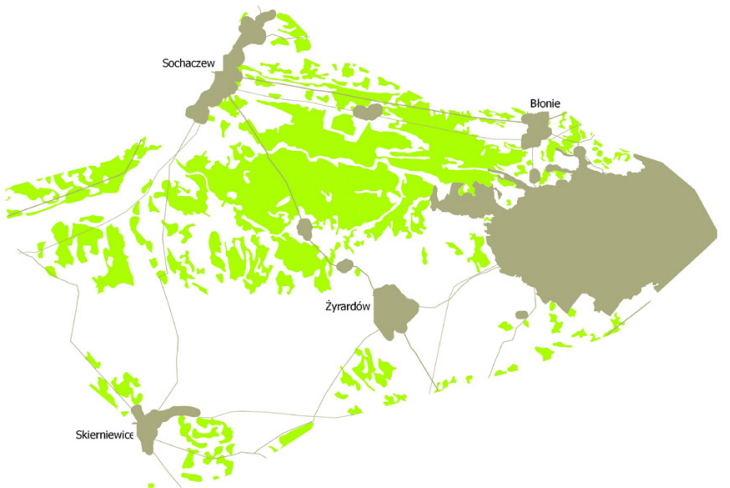

Fig. 3. Natural conditions for growing winter rape. Prepared by the authors.

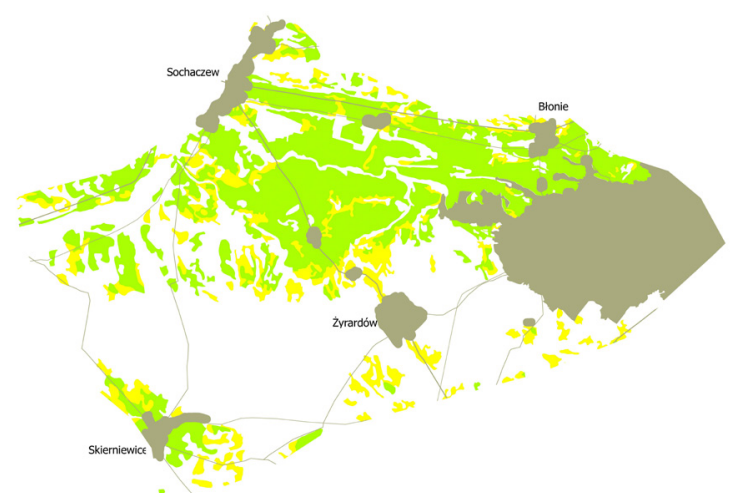

Fig. 5. Natural conditions for growing spring barley. Prepared by the authors.

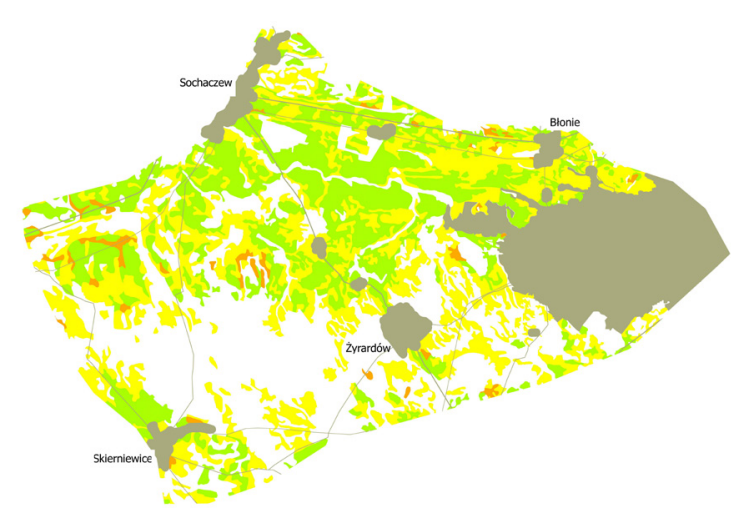

Fig. 7. Natural conditions for growing white clover. Prepared by the authors.

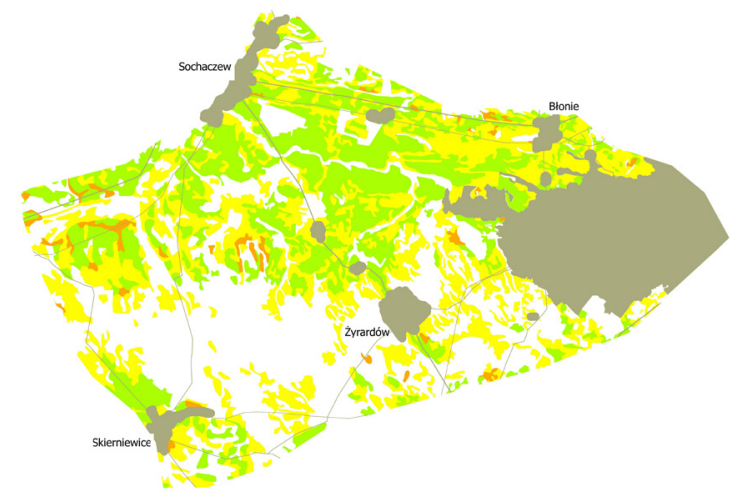

Fig. 4. Natural conditions for growing potatoes. Prepared by the authors.

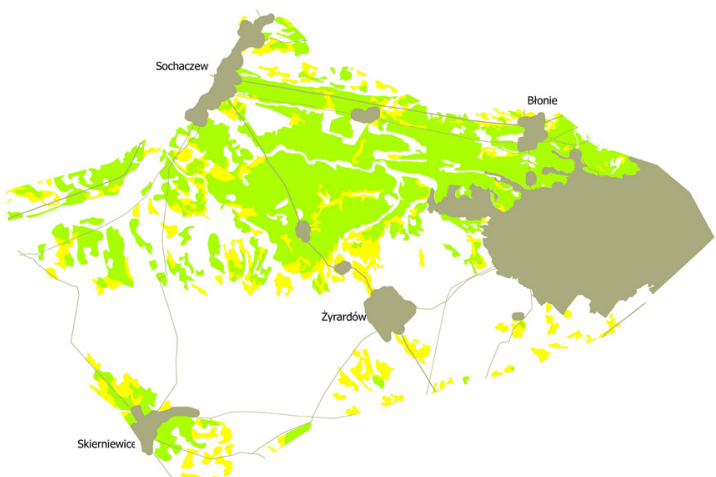

Fig. 6. Natural conditions for growing fodder beet. Prepared by the authors.
Legend
better growing conditions
good growing conditions
average growing conditions
not recommended for growing
excluded area 
buckwheat, and aftercrops of anchovy, yellow lupine and white clover. Grassland is definitely the most efficient type of land use in this area. The poorest-quality soils which evolved from aeolian sand should be afforested as these are most frequently found in the vicinity of forest areas.

An analysis of the natural conditions for individual plant species indicates that they can be classified into groups with similar requirements. Therefore some crop rotation schemes could be proposed for arable crops with similar habitat conditions, e.g.:

1. Rye, potatoes, oat, anchovy can be grown on orthic luvisols, leached brown soils and a mosaic of brown soils and orthic luvisols, in the areas which are poor, very poor or suitable for the growing of rye and in the areas with poor soils for the growing of cereals and fodder.

2. Spring barley, fodder beet, mustard, seed maize can be cultivated on mollic gleysols and cambisols in the areas which are suitable or very suitable for the growing of wheat, and suitable or very suitable for the growing of rye, cereals and fodder crops.

3. Wheat, sugar beet, oat, rape, buckwheat give yields on mollic gleysols, degraded mollic gleysols and cambisols in the areas which are suitable or very suitable for the growing of wheat.

4. Winter rape (Fig. 3), potatoes (Fig. 4), spring barley (Fig. 5), fodder beet (Fig. 6) and white clover (Fig. 7) can be grown on orthic luvisols, mollic gleysols and degraded mollic lleysols in the areas which are suitable and unsuitable for the growing of wheat, in the areas which are suitable or very suitable for the growing of rye, and those suitable for the growing of fodder crops. Potatoes can be grown in each of these crop rotation schemes (Fig. 3) as they present a broad tolerance to the granulometric content and reaction $(4.5-7 \mathrm{pH})$ of the soil.

\section{Summary}

1. The eastern part of the Łowicko-Błońska Plain has considerable natural potential for the development of sustainable agriculture. This potential is being irretrievably lost thanks to intensive development and the use of land for purposes other than farming. The areas lying along railway lines and roads are under intensive development, mostly for the building of warehouses. It is of crucial importance to disseminate knowledge and organise training for farmers in order to encourage them and facilitate sustainable agriculture. Such activities would help maintain the farming potential of this region that still remains today.

2. The majority of typical arable crops planted within the boundaries of the area proposed for integrated farming give satisfactory yields. With several crops that could be considered for cultivation in this area, appropriate crop rotation schemes could be created in order to reduce fertilisation and to maintain desirable soil properties. In this area, production should be focused on healthy plant and animal food as well as for commercial purposes.

3. The conditions for the development of organic farming within the proposed area are not as good as for integrated farming, with most plants yielding below the profitability threshold. Production of food in organic farms in the region is mainly subsistence-oriented.

4. Multi-annual planning of crop cultivation and mineral and organic fertilisation in sustainable agriculture should help improve the quality of surface and ground waters in the ŁowickoBłońska Plain.

English translation: Dorota Szmajda

\section{References}

Balkiewicz, K 2007, Zasady prowadzenia kontroli w gospodarstwach IP, pobierania prób, działania gwarantujące bezpieczeństwo płodów rolnych, IUNG, Puławy. (In Polish)

Bałazy, S, Weyssenhoff, HM \& Ziomek, K 2007, 'Kształtowanie sieci zadrzewień i ich rola na obszarach wiejskich' in Ochrona środowiska rolniczego w świetle programów rolnośrodowiskowych Unii Europejskiej, Brzesko-Poznań-Turew, pp. 127-143. (In Polish)

Ciećko, Z, Kwaśnicki, R, Przychodzeń, Z \& Ślusarski R 2007, Produkcja ekologiczna, Pomorski Ośrodek Doradztwa Rolniczego w Gdańsku, Gdańsk. (In Polish)

Corselius, K, Wisniewski, S \& Ritchie, M 2001, 'Sustainable agriculture: making money, making sense' in The Institute for Agriculture and Trade Policy, Washington, pp. 11-23.

Dobak, D 2003, 'Wody Mazowsza' in Przyroda Mazowsza i jej antropogeniczne przekształcenia, Wyższa Szkoła Humanistyczna A. Gieysztora w Pułtusku, Pułtusk, pp. 127-158. (In Polish)

Dobak, P 2003, 'Budowa Geologiczna' in Przyroda Mazowsza i jej antropogeniczne przekształcenia, Wyższa Szkoła Humanistyczna A. Gieysztora w Pułtusku, Pułtusk, pp. 61-90. (In Polish)

Dobrzański, B \& Zawadzki, S 1981, Gleboznawstwo, PWRiL, Warszawa.
(In Polish)

Faber, A 2007, Rozwój integrowanej produkcji w Polsce i na świecie, in. Integrowana produkcja roślinna, Instytut Uprawy i Nawożenia, Puławy, pp. 7-12. (In Polish)

Horrigan, L, Lawrence, RS \& Walker, 2002, 'How sustainable agriculture can address the environmental and human health harms of industrial agriculture', Environmental Health Perspectives, vol. 110, no. 5, pp. 445-456.

Kosmowska-Suffczyńska, D 2005, 'Geneza i rozwój rzeźby w czwartorzędzie' in Geografia fizyczna Polski, WN PWN Warsaw, pp. 32-71. (In Polish)

Olszewski, K 2003, 'Klimat Mazowsza' in Przyroda Mazowsza i jej antropogeniczne przekształcenia, Wyższa Szkoła Humanistyczna A. Gieysztora w Pułtusku, Pułtusk, pp. 91-102. (In Polish)

Organic farming in the European Union - facts and figures 2005, EC official website for agriculture. Available from: <http://ec.europa.eu/ agriculture/qual/organic/facts_en.pdf.>. [02 February 2007].

Pączka, S 1993, Środowisko geograficzne Polski środkowej, Wydawnictwa Uniwersytetu Łódzkiego, Łódź. (In Polish)

Program rolnośrodowiskowy PROW 2007-2013. Pakiet 1. Rolnictwo 
MISCELLANEA GEOGRAPHICA - REGIONAL STUDIES ON DEVELOPMENT

Vol. 16 • No. 1 • 2012 • pp. 5-10 • ISSN: 2084-6118 • DOI: 10.2478/v10288-012-0015-4

zrównoważone. Pakiet 2. Rolnictwo ekologiczne. Available from: <http://www.doradcaprow.pl/prow/PROW-2007-2013/DZIALANIAOSI-2/Program-rolnosrodowiskowy,94>. [12 October 2011]. (In Polish) Robak, J 2007, 'Metody ochrony roślin przed chorobami wykorzystywane w technologiach produkcji roślin warzywnych w uprawach polowych' in Integrowana produkcja roślinna, Instytut Uprawy i Nawożenia, Puławy, pp. 99-102. (In Polish)

Rodriguez, JM, Molnar, JJ, Fazio, RA, Sydnor, E \& Lowe, MJ 2008, 'Barriers to adoption of sustainable agriculture practices: change agent perspective', Renewable Agriculture and Food Systems, 24 (1), pp. 60-71.

Różycki, SZ 1972, Plejstocen Polski Środkowej, PWN, Warszawa, pp. 167-180. (In Polish)

Smagacz, J 2007, 'Rola zmianowania w integrowanej produkcji roślin' in Integrowana produkcja, Instytut Uprawy i Nawożenia, Puławy, pp. 147-154.

Stolze, M, Piorr, A, Häring, A \& Dabbert, S 2000, 'The environmental impacts of organic farming in Europe', Organic Farming in Europe: Economics and Policy, vol. 6, 1-2; 23-38, 41.

Stopa-Boryczka, M \& Boryczka, J 2006, 'Klimat' in Geografia fizyczna Polski, WN PWN Warszawa, pp. 84-127. (In Polish)

Szwejda, J 2007, 'Metody ochrony roślin przed szkodnikami wykorzystywane $w$ technologiach produkcji roślin warzywnych w uprawach polowych' in Integrowana produkcja roślinna, Instytut Uprawy i Nawożenia, Puławy, pp. 103-112. (In Polish)

Wicik, B 1992, 'Zarys krajobrazowo-geochemiczny środkowego Mazowsza na zachód od Warszawy', Prace i Studia Geograficzne, Wydawnictwa Uniwersytetu Warszawskiego, vol. 14, pp. 57-66. (In Polish)

Woś, A 1999, Klimat Polski, WN PWN, Warszawa. (In Polish)

Voivodeship Inspectorate for Environmental Protection in Lodz. Available from: <http://www.wios.lodz.pl>. [3.02.2010] . (In Polish)

Voivodeship Inspectorate for Environmental Protection in Warsaw. Available from: <http://www.wios.warszawa.pl>. [3.02.2010]. (In Polish) 